\title{
The STEP Scale: A Cross-National Scale for Short-Term Export Performance Improvement*
}

Luís Filipe Lages and Cristiana Raquel Lages **

December 2002

* This research was funded by research grants from "NOVA ÉGIDE" and "Fundação para a Ciência e Tecnologia" (Portugal / European Union) to the first author. The authors gratefully acknowledge the support of both the Warwick Business School and UMIST (UK) in conducting the surveys.

** Luis Filipe Lages is Assistant Professor of Marketing and International Business at Universidade Nova de Lisboa, Faculdade de Economia, Campus de Campolide, 1099-032 Lisboa, Portugal. E-mail: 1flages@fe.unl.pt; url:www.fe.unl.pt/ lflages; Telephone: +351.213 .801 .600 ; Fax: +351.213 .886 .073 . Cristiana Raquel Lages is affiliated with Warwick University, Warwick Business School, U.K. E-mail: c.r.c.lages@warwick.ac.uk Telephone: +44.24.7657.3749; Fax: +44.24.7652.4650. 


\title{
The STEP Scale: A Cross-National Scale for Short-Term Export Performance Improvement
}

\begin{abstract}
This paper is a direct response to a recent observation in the literature that managers appear to be short-term oriented when they assess the performance of an export venture (Madsen 1998). Based on a survey of Portuguese and British exporters, this paper presents a threedimensional scale for assessing managerial judgment of Short-Term Export Performance (the STEP scale). The three dimensions are: 1) satisfaction with short-term performance improvement; 2) short-term exporting intensity improvement; and 3) expected short-term performance improvement. The findings are used to generate implications for public policy making and managerial practice as well as directions for future research.
\end{abstract}

Keywords: Short-Term Export Performance; Export Marketing; Measurement

\section{INTRODUCTION}

“Managers' maps of export performance are often very static, narrow, and short-term oriented."

Madsen (1998: 91)

Measuring export performance is a topic of current interest for managers, public policy makers, and marketing researchers (Katsikeas, Leonidou and Morgan 2000). Research that analyzes export performance is of managerial interest as it may provide guidelines for firms reducing production costs and dependency on the domestic market, while stabilizing cyclical demand. From the point of view of governments, a better understanding of export performance is also crucial because it allows the accumulation of foreign exchange reserves, enhances societal prosperity, and helps national industries to develop, improve productivity and create new jobs (Czinkota 1994). These increasing micro and macro policy concerns with 
the exporting activity are leading to a growing interest in export performance research (Zou, Taylor and Osland 1998).

Research in the export performance topic is nearly four decades old, having been initiated with the pioneering work of Tookey (1964). Due to the innumerable difficulties associated with export performance conceptualization, operationalization and measurement, it was not possible to find consensus during this period on a unique export performance construct. The existing diversity of measures impacts on the reliability of existing findings, as researchers question if existing performance findings are a consequence of independent variables or a consequence of export performance operationalization (Zou, Taylor and Osland 1998). To overcome this state of affairs, a few notable efforts to advance export theory have been made in recent years, through the development of broad export performance scales that can be used to compare findings across different national settings (e.g. Zou, Taylor and Osland 1998; Styles 1998). Nevertheless, and despite the fact that "managers' maps of export performance are often very static, narrow and short-term oriented" (Madsen 1998: 91), none of these studies was particularly concerned with the assessment of Short-Term Export Performance (STEP).

In this paper, we develop the cross-national STEP scale, because an integrated approach to short-term performance measurement is still lacking. This is a particularly important topic at both micro and macro levels because it is not possible to make future decisions without evaluating export ventures in the short-term (Madsen 1998). When assessing performance both managers and public policy makers have a high emphasis on short-term factors, and are particularly worried about setting annual targets and assessing annual export performance improvement (Lages and Montgomery 2003).

At the micro-level, the short-term view is important because current strategy is determined as a function of its expected effects on short-term performance. Furthermore, future short-term 
decisions are influenced by current performance levels, as recently confirmed by research of Lages and colleagues (Lages 1999; Lages and Melewar 2001; Lages and Montgomery 2002). It is expected that poor/successful performance in export operations has an immediate impact on strategic decisions. When performance decreases in any given year, both internal (e.g., top management, employees, union representatives) and external (e.g., shareholders/investors, suppliers, and credit institutions) publics will consider it a potential threat to the whole organization, demanding in turn immediate improvements in short-term export performance. Moreover, many firms depend on short-term performance for survival. This is particularly true of firms that lack financial resources as well as those operating in markets with low margins (due to a high level of competition or market saturation). From the point of view of a manager, there is also a common practice of focusing on annual performance results because it is much easier to establish and quantify results annually than in the long-term. Furthermore, managers consider short-term performance vital because it relates to their own personal interests. In recent years, there has been an increasing mobility of managers across firms, and top managers spend fewer years within the same organization. Moreover, performance improvement at the end of the year might have an immediate effect in terms of personal income (e.g. salary bonus). This might lead them to place more importance on short-term performance.

At the macro-level, short-term performance is equally important. All the benefits provided by the exporting activity encourage public policy makers to implement export promotion programs with the objective of helping firms improve their competitive advantage and ultimately enhance their performance in the international arena (Lages and Montgomery 2003). Particularly in times of recession, some countries look to the export activity for shortterm solutions, such as decreasing the nation's budget deficit. A decrease in national firms' export performance might put pressure on public policy makers to support the export activity 
and demand from managers a better allocation of the assistance received. As is the case with managers, public policy actions are constantly evaluated by several publics, and consequently have (dis)incentives accordingly (e.g. being re-elected, or not). Naturally, if they want to remain active they need to be concerned with national firms' short-term export performance, as this will have a direct impact on a country's economic health.

The implication of all these considerations is that while long-term export performance is crucial, if the exporting activities of the firm are successful in the short term, it will be extremely difficult for both managers and public policy makers to focus on the future. Altogether, this provides support to Madsen's view (1998: 82) that "the real world is not as simple as the economic theory, according to which the long-term profitability or maximization of rent-earning abilities are the ultimate goals for the firm." Managers appear to be short-term oriented when defining their strategies and assessing the performance of an export venture.

In sum, this paper aims to develop a short-term export performance measure, the STEP scale, that can be applied to multiple countries with the final objective of helping managers and public policy makers to assess the performance of short-term exporting ventures. The STEP scale will allow one to identify the effects of previous actions on current performance and will help in the development of future tactical and strategic decisions. Furthermore, it will contribute to properly allocating scarce resources to the right ventures. Finally, through the STEP scale we expect to contribute to theory development by providing a unified measure for capturing cross-national short-term performance, which will contribute to a greater consensus in future literature exploring the topic of short-term performance.

In the first part of this paper we develop the STEP scale. This scale is tested via a survey of Portuguese and British exporting managers. The results are presented and then its implications for theory are discussed. We conclude with the implications of these results for 
public policy making and managerial practice, and finally consider the limitations of the research and fruitful directions for future research.

\section{THE STEP SCALE: A SCALE FOR SHORT-TERM EXPORT PERFORMANCE}

In the export marketing literature researchers have used a wide-ranging array of measures to assess performance as there is no established definition of performance. This lack of consensus may be due to the fact that performance itself is a complex construct in the view of the firm (Greve 1998). It is often idiosyncratic to the firm and setting; success for one company may constitute failure for another.

For research purposes, it is often impossible to establish a common definition or fixed reference points across firms. This might be because managers tend to use their own perceptions of performance, rather than objective values, in order to formulate their own decisions (Bourgeois 1980). In broad terms an individual export venture is successful when targets are met or exceeded. However, it is extremely difficult to achieve agreement on this issue. Both stakeholders and managers in different firms may have a different view on which operational measures to use when setting targets and, hence, it becomes very difficult to find agreement on how to assess export performance (Madsen 1998).

One of the purposes of this study is to identify key managerial perceptions with regard to export performance assessment. As the unit of analysis is a specific export venture, responding executives have detailed knowledge of its export performance and use this knowledge to develop their marketing strategies. Improving from a very good position in the previous year may be much more difficult than improving from a bad position. By measuring perceived performance, instead of performance per se, researchers are able to capture the degree to which performance has matched the aspiration levels of the firm from one year to the next and to compare it across a variety of exporting firms. In this manner, a boundary line 
is incorporated and used as a reference point for perceived success and failure. It also serves as a useful starting point for decision-making.

In order to partially overcome the problem of performance measurement, one approach that is increasingly relied upon is the aggregation of various performance measures into a single measure of export performance (cf. Diamantopoulos and Winklhofer 2001; Katsikeas, Leonidou, and Morgan 2000). This is the approach incorporated here. In the pages below, we develop a measurement scale for short-term export performance that incorporates 1) satisfaction with short-term performance improvement; 2) short-term exporting intensity improvement; and 3) expected short-term performance improvement in a one-year period. We use this approach of using the one-year time frame to assess short-term export performance as it is already established in the literature (e.g. Cooper and Kleinschmidt 1985; Kaynak and Kuan 1993; Lages and Montgomery 2003).

Satisfaction with short-term performance improvement is defined as a compound psychological variable (an affective state) assessing the effectiveness of a marketing program in terms of its sales, profitability, and market share, as well as overall performance (cf. Bonoma and Clark 1988) from one year to the next. This measure is crucial in assessing export performance as it covers managers' beliefs on how well they are meeting their exporting goals while dealing with some objective measures of export performance (e.g. sales volume and profitability) (Wang and Olsen 2002). Satisfaction in assessing export performance is also one of the most studied outcome variables in the marketing literature (see Geyskens, Steenkamp, and Kumar 1999 for a review), being well established in the export marketing field (e.g., Lages and Melewar 2001; Shoham 1998; Zou, Taylor and Osland 1998).

The dimension "short-term exporting intensity improvement" is used to assess managers' perceived importance of the exporting activity (in terms of sales volume and profitability) to 
a firms' overall performance from one year to the next. Traditionally, export performance has been measured by export sales intensity, as this variable is associated with most aspects of export behavior (Bilkey and Tesar 1977; Cavusgil and Nevin 1981; Zhao and Zou 2002). A recent meta-analysis of export performance studies (Katsikeas, Leonidou, and Morgan 2000) indicates that export sales intensity is the most common measure in the literature $(61 \%$ of the reviewed studies in export marketing have used this measure). In this study, and similarly to previous empirical studies (e.g. Beamish, Craig, and McLellan 1993; Bilkey 1982; Kotabe and Czinkota 1992), we also use profit intensity in addition to export sales intensity. Some researchers might argue that the use of export intensity may have some shortcomings, such as the fact that a higher export performance intensity does not necessarily imply higher export performance. Nevertheless, this export performance measure is already established in the export performance literature (Leonidou, Katsikeas and Samiee 2002). Furthermore, previous research (e.g., Lages 2000; Lages and Melewar 2001; Shoham 1998) has already demonstrated the existence of a strong association between this measure and other export performance measures.

The third dimension of the STEP scale is expected short-term performance improvement. By asking managers about the expected short-term performance improvement, they will be able to report on their expectations of improvement from one year to the next while taking into consideration their own perception of their firm's reference groups. Similarly to export performance intensity, some researchers might also argue that the use of expected export performance improvement does not necessarily imply higher export performance in the current year. However, previous research reveals that current strategy is determined as a function of its expected effects on short-term performance. Furthermore, performance levels tend to reinforce one another from period to period. This works in two ways. When the firm performs well, internal publics (e.g. employees, union representatives) and external publics 
(e.g. clients/customers, suppliers, investors, and credit institutions) are more likely to react favorably to the firm, thus facilitating continued performance improvement (Isen and Baron 1991). On the other hand, poor performance may negatively influence performance in the next period, as the reputation of both the firm and top management are spoiled by poor performance (Sutton and Callahan 1987). The perception of failure on the part of the different entities interacting with the company, enhanced by the firm's internal instability, will lead the organization into vicious cycles of "unsuccess" (Masuch 1985). This explains why previous empirical research has shown a strong correlation between this measure and other export performance measures (e.g. Wang and Olsen 2002).

\section{METHOD}

\section{THE RESEARCH SETTING}

Our research setting is in Portugal and the U.K., two member countries of the European Union (EU). The EU is the world's largest exporter of goods, maintaining a stable share of approximately one fifth of total world exports (intra-EU trade excluded) since 1990 (European Commission 2000). As in many other EU countries, both Portuguese and British economic growth depends heavily on the exporting success of national firms. Our focus is on a single export venture, as this approach of a single product or product line exported to a single foreign market will allow future researchers using these measures to associate export performance more precisely with its antecedents and outcomes.

\section{SURVEY INSTRUMENT DEVELOPMENT}

In both countries, a questionnaire was developed that incorporates a variety of multiitem measures and indicators of the conceptual framework. Additional indicators derived from exploratory interviews in the research context were also included.

The questionnaire was initially developed in English and then translated into Portuguese. The content and face validity of the items was assessed by four judges 
(university lecturers in marketing); each judge was asked to assess how representative each item was of the final construct. The survey was revised according to their comments. It was then given to a pretest sample of fifteen managers involved in export operations. The pretest results were used to further refine the questionnaire. In order to avoid translation errors, the questionnaire was translated into English by a different researcher. A full listing of the final items and their scale reliabilities for Portugal and the U.K. can be found in the Appendix. The average internal reliability (Cronbach alpha) for the Portuguese sample was .93 and for the British sample .87 .

\section{DATA COLLECTION PROCEDURE}

\section{Portugal}

A sample of 2,500 firms was randomly generated from a government agency database of Icep-Portugal (1997). This database of 4,765 Portuguese exporters was the most comprehensive and up-to-date database available in the Portuguese market at the time of data collection (1999). The pretest results indicated a strong need for an incentive to motivate the respondents to participate. In the cover letter it was stated that in return for a completed survey respondents would be provided with a list of potential overseas importers or clients, along with a report of the final results. Additionally, confidentiality was assured.

In the first mailing, a cover letter, a questionnaire, and an international postage-paid business reply envelope was sent to the person responsible for exporting in each of the 2,500 Portuguese firms. This missive was followed by a second mailing that included a reminder letter and a reply envelope. Of the sample of 2,500 Portuguese managers, 29 stated that they no longer exported and 119 questionnaires were returned by the mailing service. These firms had either closed down or moved without leaving a forwarding address. Thus, the sample size was reduced to 2,352. Of these, 519 questionnaires were returned, a $22 \%$ response rate. 


\section{United Kingdom}

A sample of 1564 British enterprises was randomly generated from a database of the British Chamber of Commerce on "British Exports, 2000" (Reed Business Information 2000). An incentive was stated in the cover letter: in return for a completed questionnaire, the findings would be available after the completion of the study. Confidentiality was also assured.

As with the Portuguese survey, a cover letter, a questionnaire and a postage-paid business reply envelope were sent to the person responsible for exporting in each of the British firms under study. Unfortunately, in contrast to the Portuguese survey, it was not possible to obtain governmental funding to conduct the research. Consequently, due to lack of financial resources, it was not possible to send a reminder mailing.

The data collection was conducted in 2002. Similarly to the method recently used by Menon et al. (1999), 100 randomly chosen respondents were contacted to determine nondeliverable and noncompliance rates, and finally assess response rates. We determined that $34 \%$ of the mailings were nondeliverable because of incorrect address; an additional 40\% did not reach the person responsible for the export operations in the firm; and $4 \%$ of the respondents reported a corporate policy of not responding to academic surveys. The total of 111 usable returned questionnaires represents a $31 \%$ response rate, which is quite satisfactory, given that average top management survey response rates are in the range of $15 \%-20 \%$ (Menon, Bharadwaj, and Howell 1996; Menon et al. 1999).

\section{ASSESSMENT OF NON-RESPONSE BIAS AND DATA PROFILE}

Non-response bias was tested by assessing the differences between the early and late respondents with regard to the means of all the variables for both samples (Armstrong and Overton 1977). Early respondents were defined as the first $75 \%$ of the returned questionnaires, and the last $25 \%$ were considered to be late respondents. No significant 
differences among the early and late respondents were found, suggesting that response bias was not a significant problem in the study.

The whole size range of firms is represented in the sample. Both Portuguese and British exporting industries are primarily composed of SMEs. Of the exporting firms represented in the sample, $5 \%$ of Portuguese firms and $6 \%$ of British companies have less than 500 employees. With regard to the Portuguese sample, the average annual export sales of these firms ranged from $\$ 350.000$ - $\$ 1.5 \mathrm{M}$ US. With regard to the British sample, the average annual export sales of these firms ranged from $\$ 470.000$ - \$1.6 M US.

Both surveys were directed to individuals who were primarily responsible for exporting operations and activities. The job title of these individuals ranged from president to marketing director, managing director, or exporting director. Respondents in both countries were asked to indicate their degree of experience in exporting on a scale where $1=$ none and $5=$ substantial. The mean response for Portugal was $3.6(\mathrm{sd}=.84$, range 1 to 5$)$ and for the UK was $3.8(\mathrm{sd}=.93$, range 1 to 5$)$. Collectively, this indicates that although the title of the respondents' positions may be wide-ranging, the individuals appear to have significant knowledgeable in the specific exporting activities of the firm and are experienced with exporting in general.

\section{DATA ANALYSIS}

\section{CONFIRMATORY FACTOR ANALYSIS}

Churchill's (1979) traditional approach to scale development was used. As noted by Churchill (1979), in order to increase reliability and decrease measurement error it is more advisable to use multi-item scales than single item scales. Churchill's (1979) approach to scale development has been expanded by Gerbing and Anderson (1988) with the use of Confirmatory Factor Analysis (CFA). We used CFA to assess the measurement properties of 
the existing scales, using full-information maximum likelihood (FIML) estimation procedures in LISREL 8.3 (Jöreskog and Sörbom 1993). CFA provides a better estimate of reliability than coefficient alpha (Steenkamp and Van Trijp 1991). While coefficient alpha assumes that different indicators have equal factor loadings $(\lambda)$ and error variances $(\delta)$, CFA takes into account the differences among the existing indicators (Styles 1998).

\section{FACTORIAL SIMILARITY}

The first step in developing a cross-national validation of our scale was to test factorial similarity across the Portuguese and British samples (Mullen 1995; Singh 1995; Styles 1998). Two measurement models were developed for each sample. Each item is restricted to load on its pre-specified factor, with the error variances and factor loadings allowed to correlate freely.

The chi-square for both models is significant (Portugal: $\chi^{2}=129.73,32 \mathrm{df}, \mathrm{p}<.00$; U.K.: $\left.\chi^{2}=70.42,32 \mathrm{df}, \mathrm{p}<.00\right)$. Since the chi-square statistic is sensitive to sample size, we also assessed additional fit indices: the Normed Fit Index (NFI), the Non-Normed Fit Index (NNFI), the Comparative Fit Index (CFI) and the Incremental Fit Index (IFI). All the fit indices for the Portuguese sample $(\mathrm{NFI}=.98 ; \mathrm{NNFI}=.98, \mathrm{CFI}=.98$ and $\mathrm{IFI}=.98)$ present satisfactory values. Similarly, with regard to the British sample, the NFI, NNFI, CFI and IFI are $.91, .93, .95$, and .95 , respectively, suggesting that the model fits the data well.

Convergent validity is evidenced by the large and significant standardized loadings of each item on its intended construct (average loading size was .90 for the Portuguese sample, and .84 for the British sample). Table 1 shows the factor loadings and t-values for both models.

Insert Table 1 about here

$* * * * * * * * * * * * * * * * * * * * * * * * * * * * * * * * * * * * * * *$

Discriminant validity among the constructs was rigorously assessed using the Fornell and Larcker (1981) test; all possible pairs of constructs passed this test. 


\section{FACTORIAL EQUIVALENCE AND MEASUREMENT EQUIVALENCE}

After testing for factorial similarity, we tested factorial and measurement equivalence using LISREL 8.3 (Jöreskog and Sörbom 1993). In order to test equality of the factor structure, we ran three multi-sample models (see Table 2: Model A, Model B, Model C). First, we allowed both factor loadings and error variance to be different for the two groups, assuming that the factor correlation was the same. This multi-sample model (Model A) presented a chi-square of $190.18(67 \mathrm{df}, \mathrm{p}<.00)$ and the following fit indices: $\mathrm{NFI}=.97 ; \mathrm{NNFI}=.97, \mathrm{CFI}=.98$ and $\mathrm{IFI}=.98$. Second, we allowed the factor loadings to be different for the two sample groups, while maintaining the invariance of the factor correlation and error variance. This model (Model B), presented a chi-square of $395.71(77 \mathrm{df}, \mathrm{p}<.00)$ and the following fit indices: $\mathrm{NFI}=.95 ; \mathrm{NNFI}=.95, \mathrm{CFI}=.96$ and $\mathrm{IFI}=.96$. Third, the error variance was different for the two groups, and we held factor correlation and factor loadings equal for both groups. This multi-sample model (Model C) presented a chi-square of $212.97(77 \mathrm{df}, \mathrm{p}<.00)$ and the following fit indices: $\mathrm{NFI}=.96 ; \mathrm{NNFI}=.97, \mathrm{CFI}=.98$ and $\mathrm{IFI}=.98$. In sum, although the chisquares for the three multi-sample models are significant, the fit indices suggest factorial equivalence.

Finally, in order to test full metric equivalence, we used a constrained model (see Table 2: model D) in which we assumed that all the parameters were the same in both groups. Hence, factor correlations, factor loadings, and error variances were invariant for the two groups. Despite the significant chi-square $\left(\chi^{2}=422.04,87 \mathrm{df}, \mathrm{p}<.00\right)$, the fit indices suggested metric equivalence $(\mathrm{NFI}=.94 ; \mathrm{NNFI}=.95, \mathrm{CFI}=.95$ and $\mathrm{IFI}=.95)$.

Insert Table 2 about here

$* * * * * * * * * * * * * * * * * * * * * * * * * * * * * * * * * * * * * * *$ 
In conclusion, our validation across the Portuguese and British samples suggests that the STEP scale might be cross-nationally applied, because it presents factorial similarity, factorial equivalence and measurement equivalence.

\section{CONCLUSION}

\section{MANAGERIAL AND PUBLIC POLICY IMPLICATIONS}

The STEP scale presents a cross-national evaluation of firms' short-term performance. Several reasons justify the need to have a sound evaluation of short-term export performance. The STEP scale might help managers to monitor performance in the short term, allowing them to take short-term performance as a reference point when defining future actions, as well as when allocating resources to specific export ventures. From the point of view of public policy makers, if one considers that long-term success in export allocation is also a result of short-term actions, public policy makers will favorably view a new scale to assess short-term export performance. This scale might be used cross-nationally to assess the relationship between the export assistance offered and short-term performance improvements in firms receiving that support. A proper allocation of export assistance in the short term will allow public policy makers to save resources that can be used to generate reserves or save resources that can be allocated to other activities.

\section{RESEARCH LIMITATIONS}

The first limitation of this research is related to the size of the British sample. The British sample size is small, and, consequently, these results should be regarded as suggestive rather than conclusive. A possible second limitation is that our research instrument (i.e. the questionnaire) may have created common method variance. This could be particularly threatening if the respondents were aware of the conceptual framework of interest. However, they were not told the specific purpose of the study, and all of the construct items were 
separated and mixed. Hence, the biasing possibilities of common method variance were partially minimized (Lages and Montgomery 2003).

\section{DIRECTIONS FOR FUTURE RESEARCH}

Major advances in export marketing will only be made possible by means of a more integrated approach to conceptualizing and measuring export performance (Cavusgil and Zou 1994; Shoham 1998). In this paper we develop the STEP scale, a cross national scale to assess short-term export performance using 3 dimensions: 1) satisfaction with short-term performance improvement; 2) short-term exporting intensity improvement; and 3) expected short-term performance improvement. Instead of treating the STEP scale as a unidimensional construct, various measurement units for each of the three dimensions are presented. In order to refine the STEP scale presented here, the replication of this study across various industries, and particularly across different countries, is suggested.

When assessing export performance, future research should be concerned with exploring the short-time horizon frequently used by managers and public policy makers to assess performance (Madsen 1998). If one considers the long-term failures and successes of the firm as a function of its short-term actions, it is clear that future research that looks into understanding short-term performance, as well as its antecedents and effects, can yield valuable insights into improving long-term performance. Organizations and individuals constantly set goals and adjust their behavior in response to favorable and unfavorable feedback (Cyert and March 1963; March and Simon 1958). The scale presented here helps to assess this feedback. International marketing researchers should simultaneously consider how past strategy impacts on short-term performance, as well as how short-term performance impacts on strategy, as strategic decisions are motivated by a combination of short-term proactive and reactive behaviors (March and Sutton 1997). By better understanding the one- 
year relationship between strategy and performance, researchers might help managers to avoid being caught in a vicious cycle of successive unsatisfactory results.

In sum, international business scholars are now being challenged to state their managerial and public policy implications more clearly (Czinkota 1994; Madsen 1998). In trying to meet this call, our research seeks to capture practical knowledge within a theoretical framework. It is believed that these combined perspectives of theory and practice focus our research agenda. Moreover, we suggest, in conceptual argument and methodological development, that using a short-term time frame of one year might assess export performance in a novel way. More specifically, this research creates the cross-national STEP scale that measures improvement in short-term export performance, which may align real world time constraints with methodological soundness. 
TABLE 1:

CFA RESULTS FOR PORTUGUESE AND BRITISH SAMPLE

Note: $\alpha=$ Internal reliability (Cronbach 1951$)$

Portuguese exporters: Year 1=1997; Year 2=1998

British exporters: Year 1=2000; Year 2=2001

\begin{tabular}{|c|c|c|c|c|c|c|c|}
\hline \multirow{2}{*}{$\begin{array}{l}\text { Dimensions of } \\
\text { Short-Term Export } \\
\text { Performance }\end{array}$} & \multirow[t]{2}{*}{ Items } & \multicolumn{3}{|c|}{ Portugal } & \multicolumn{3}{|c|}{ United Kingdom } \\
\hline & & $\alpha$ & $\begin{array}{l}\text { Stand. } \\
\text { Item- } \\
\text { Loading }\end{array}$ & $\begin{array}{c}\mathrm{T}- \\
\text { value }\end{array}$ & $\alpha$ & $\begin{array}{l}\text { Stand. } \\
\text { Item- } \\
\text { Loading }\end{array}$ & $\begin{array}{c}\text { T- } \\
\text { value }\end{array}$ \\
\hline
\end{tabular}

SAT Satisfaction with Short-Term Performance Improvement .95

How satisfied are you with the results of your

export venture from Year 1 to Year 2?

$1=$ much less satisfied in Year 2 than in Year 1
$5=$ much more satisfied in Year 2 than in Year 1

SAT1

- Export sales volume

$.93 \quad 27.85$

27.85

.82

- Export profitability

$\begin{array}{rr}.89 & 25.88 \\ 87 & 24.94\end{array}$

.69

SAT3

- Market share in the main importing market

24.94

10.05

SAT4 - Overall export performance

INT Short-Term Exporting Intensity Improvement

With regard to your export venture, to what extent did the following change from Year 1 to Year 2?

$$
\begin{aligned}
& 1=\text { large decrease from Year } 1 \text { to Year } 2 \\
& 5=\text { large increase from Year } 1 \text { to Year } 2
\end{aligned}
$$

INT1 - Percentage of exporting venture to total sales volume

INT2 - Percentage of exporting venture to total profitability

\section{EXP Expected Short-Term Performance Improvement}

What do you anticipate the results of your exporting venture will be this year compared to the past year?

$$
\begin{aligned}
& 1=\text { worsen significantly } \\
& 5=\text { improve significantly }
\end{aligned}
$$

EXP1 - Export sales volume of the export venture

EXP4 - Satisfaction with the exporting venture 
TABLE 2

CFA RESULTS FOR TWO GROUP MODEL

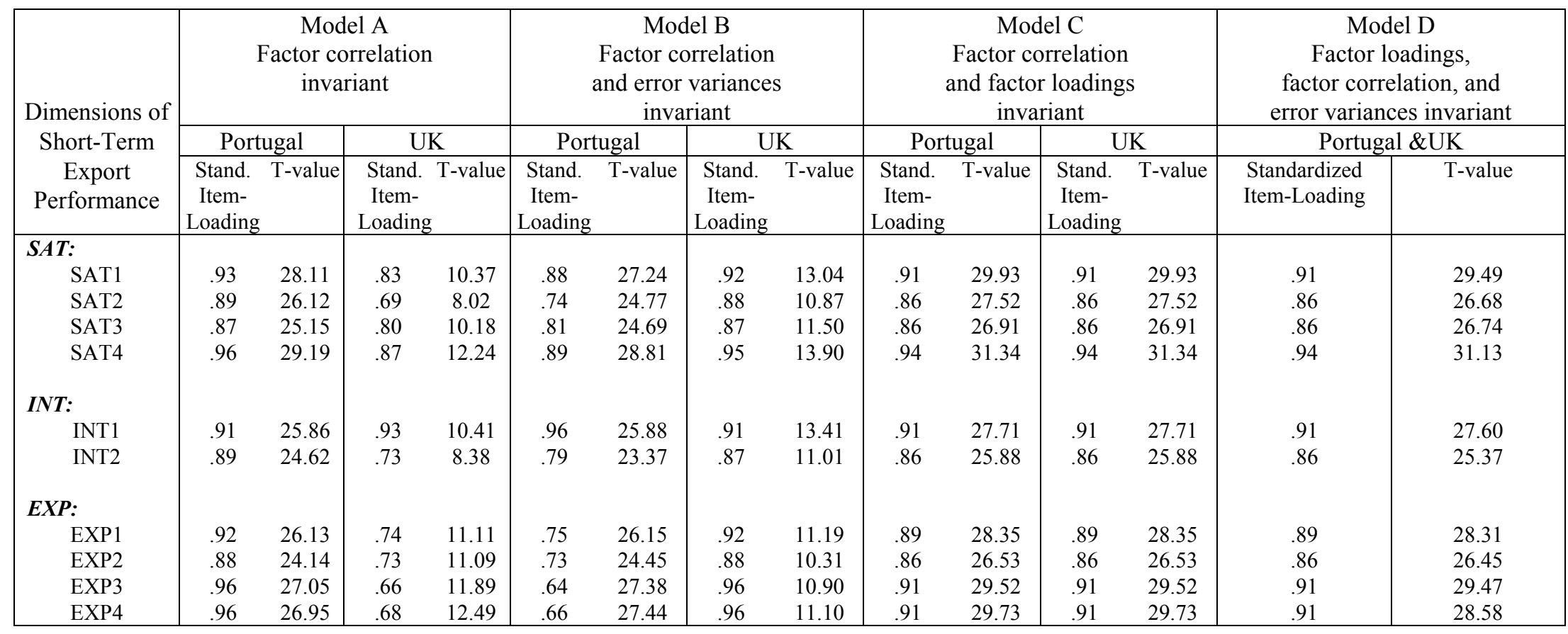

\begin{tabular}{|c|c|c|c|c|}
\hline \multirow{3}{*}{ Fit Indices } & $\chi^{2}=190.18,67 \mathrm{df}, \mathrm{p}<.00$ & $\chi^{2}=395.71,77 \mathrm{df}, \mathrm{p}<.00$ & $\chi^{2}=212.97,77 \mathrm{df}, \mathrm{p}<.00$ & $\chi^{2}=422.04,87 \mathrm{df}, \mathrm{p}<.00$ \\
& NFI $=.97 ; \mathrm{NNFI}=.97$ & $\mathrm{NFI}=.95 ; \mathrm{NNFI}=.95$ & NFI $=.96 ; \mathrm{NNFI}=.97$ & $\mathrm{NFI}=.94 ; \mathrm{NNFI}=.95$ \\
& CFI $=.98 ; \mathrm{IFI}=.98$ & $\mathrm{CFI}=.96 ; \mathrm{IFI}=.96$ & $\mathrm{CFI}=.98 ; \mathrm{IFI}=.98$ & $\mathrm{CFI}=.95 ; \mathrm{IFI}=.95$ \\
\hline
\end{tabular}




\section{REFERENCE LIST}

Armstrong, J. S., \& Overton, T. S. (1977). Estimating nonresponse bias in mail surveys. Journal of Marketing Research, 16(Aug), 396-400.

Beamish, P. W., Craig, R., \& McLellan, L. (1993). The performance characteristics of Canadian versus U.K. exporters in small and medium sized firms. Management International Review, 33(2), 121-137.

Bilkey, W. J. (1982). Variables associated with export profitability. Journal of International Business Studies, 13(Fall), 39-55.

Bilkey, W. J., \& Tesar, G. (1977). Export behavior of smaller sized Wisconsin manufacturing firms. Journal of International Business Studies, 8, 93-99.

Bonoma, T. V., \& Clark, B. H. (1988). Marketing performance assessment. Boston, Mass.: Harvard Business School Press.

Bourgeois, L. J. (1980). Performance and consensus. Strategic Management Journal, 1, 227248.

Cavusgil, S. T., \& Nevin, J. R. (1981). Internal determinants of export marketing behavior: An empirical investigation. Journal of Marketing Research, 18(February), 114-119.

Cavusgil, S. T., \& Zou, S. (1994). Marketing strategy-performance relationship: An investigation of the empirical link in export market ventures. Journal of Marketing,

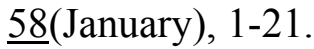

Churchill, G. A. (1979). A paradigm for developing better measures of marketing constructs. Journal of Marketing Research, 26(Feb), 64-73.

Cooper, R. G., \& Kleinschmidt, E. J. (1985). The impact of export strategy on export sales performance. Journal of International Business Studies, 16(Spring), 37-55.

Cyert, R. M., \& March, J. G. (1963). A Behavioral Theory of the Firm. Englewood Cliffs, N.J.: Prentice-Hall.

Czinkota, M. R. (1994). A national export assistance policy for new and growing businesses. Journal of International Marketing, 2(1), 91-101.

Diamantopoulos, A., \& Winklhofer, H. M. (2001). Index construction with formative indicators. Journal of Marketing Research, 38(May), 269-277.

Fornell, C., \& Larcker, D. (1981). Evaluating structural equation models with unobservable variables and measurement error. Journal of Marketing Research, 28(Feb), 39-50.

Gerbing, D. W., \& Anderson, J. C. (1988). An updated paradigm for scale development incorporating unidimensionality and its assessment. Journal of Marketing Research, 25(May), 186-192.

Geyskens, I., Steenkamp, J.-B., \& Kumar, N. (1996). The effects of trust and interdependence on relationship commitment: A trans-atlantic study. International Journal of Research 
in Marketing, (Oct), 303-317.

Greve, H. R. (1998). Performance, aspirations, and risky organizational change. Administrative Science Quarterly, 43, 58-86.

ICEP. (1997). CD-Export Database: Disk 1. European Union: Dataware Technologies.

Isen, A. M., \& Baron, R. A. (1991). Positive affect as a factor of organizational behavior. In Research in Organizational Behavior (L. L. Cummings and B. M. Staw ed.). Greenwich, CT: JAI Press.

Jöreskog, K. G., \& Sörbom, D. (1993). LISREL 8: Structural equation modeling with the SIMPLIS command language. Chicago: Scientific Software International, Inc.

Katsikeas, C. S., Leonidou, L. C., \& Morgan, N. A. (2000). Firm-level export performance assessment: Review, evaluation, and development. Journal of the Academy of Marketing Science, 28(4), 493-511.

Kaynak, E., \& Kuan, W. K.-Y. (1993). Environment, strategy, structure, and performance in the context of export activity: An empirical study of Taiwanese manufacturing firms. Journal of Business Research, 27(1), 33-49.

Kotabe, M., \& Czinkota, M. R. (1992). State government promotion of manufacturing exports: A gap analysis. Journal of International Business Studies, 23(4), 637-658.

Lages, L. F. (1999). Marketing lessons from Portuguese wine exporters: The development and application of a conceptual framework. Journal of Wine Research, 10(ii), 123132.

Lages, L. F. (2000). A conceptual framework of the determinants of export performance: Reorganizing key variables and shifting contingencies in export marketing. Journal of Global Marketing, 13(3), 29-51.

Lages, L. F., \& Melewar, T. C. (2001). Linking management forces, marketing standardization and export performance: Empirical evidence from Portuguese SMEs. 30th European Marketing Academy Conference, CD Rom Proceedings, Bergen, Norway, 8-11 May.

Lages, L. F., \& Montgomery, D. B. (2002). Rethinking the determinants of export marketing strategy: Empirical evidence from SMEs. In Lorraine Eden Geographies and International Business, Proceedings of the 44th AIB Conference . Puerto Rico, USA: Academy of International Business.

Lages, L. F., \& Montgomery, D. B. (2003). Analyzing the short term link between public policy support and export performance improvement: The importance of the mediating effects of price strategy. What's New? What's Next? In Marketing Theory, Education, and Practice, Proceedings of the 2003 AMA Winter Marketing Educators' Conference . Orlando, USA: American Marketing Academy.

Leonidou, L. C., Katsikeas, C. S., \& Samiee, S. (2002). Marketing strategy determinants of export performance: A meta-analysis. Journal of Business Research, 55, 51-67.

Madsen, T. K. (1998). Executive insights: Managerial judgment of export performance. Journal of International Marketing, 6 (3), 82-93. 
March, J. G., \& Simon, H. A. (1958). Organizations. New York: John Wiley \& Sons.

March, J. G., \& Sutton, R. I. (1997). Organizational performance as a dependent variable. Organization Science, 8(6), 698-706.

Masuch, M. (1985). Vicious circles in organizations. Administrative Science Quarterly, 30, 14-33.

Menon, A., Bharadwaj, S. G., Adidam, P. T., \& Edison, S. W. (1999). Antecedents and consequences of marketing strategy making: A model and a test. Journal of Marketing ,63(April), 18-40.

Menon, A., Bharadwaj, S. G., \& Howell, R. D. (1996). The quality and effectiveness of marketing strategy: Effect of functional and dysfunctional conflict in intraorganizational relationships. Journal of the Academy of Marketing Science, 24(Fall), 299-313.

Mullen, M. (1995). Diagnosing measurement equivalence in cross-national research. Journal of International Business Studies, 26(3), 537-596.

Reed Business Information. (2000). British Exports. Windsor: Kompass Publishers.

Shoham, A. (1998). Export performance: A conceptualization and empirical assessment. Journal of International Marketing, 6(3), 59-81.

Singh, J. (1995). Measurement issues in cross-national research. Journal of International Business Studies, 26(3), 597-620.

Steenkamp, J.-B., \& Van Trijp, H. C. M. (1991). The use of LISREL in validating marketing constructs. International Journal of Research in Marketing, 8, 283-289.

Styles, C. (1998). Export performance measures in Australia and the United Kingdom. Journal of International Marketing, 6(3), 12-36.

Sutton, R. I., \& Callahan, A. L. (1987). The stigma of bankruptcy: Spoiled organizational image and its management. Academy of Management Journal, 30(Sep), 405-436.

Tookey, D. A. (1964). Factors associated with success in exporting. The Journal of Management Studies, 1(Mar), 48-66.

Wang, G., \& Olsen, J. E. (2002). Knowledge, performance and exporter satisfaction: An exploratory study. Journal of Global Marketing, 15(3/4), 39-64.

Zhao, H., \& Zou, S. (2002). The impact of industry concentration and firm location on export propensity and intensity: An empirical analysis of Chinese manufacturing firms. Journal of International Marketing, 10(1), 52-71.

Zou, S., Taylor, C. R., \& Osland, G. E. (1998). The EXPERF scale: A cross-national export performance measure. Journal of International Marketing, 6(3), 37-58. 